\title{
Dalton

\section{The role of the Cys-X-X-X-Cys motif on the kinetics of cupric ion loading to the Streptomyces lividans Sco protein $\dagger$}

\author{
Katie L. I. M. Blundell, ${ }^{a}$ Michael T. Wilson, ${ }^{a}$ Erik Vijgenboom ${ }^{b}$ and \\ Jonathan A. R. Worrall*a
}

\begin{abstract}
The mechanisms and spectroscopic properties generated by intermediate states upon cupric ion binding to flexible peptide motifs in proteins are of considerable interest. One such motif is the Cys-X-X-X-Cys motif characteristic to members of the Sco family of proteins. In the antibiotic producing bacterium, Streptomyces lividans, a role for its Sco protein $\left(\mathrm{Sco}^{\mathrm{Sl}}\right)$ as a cupric metallochaperone to the extracytoplasmic $\mathrm{Cu}_{\mathrm{A}}$ domain of cytochrome $\mathrm{c}$ oxidase has been revealed. Stopped-flow kinetic studies have revealed a mechanism of cupric ion capture by $\mathrm{ScO}^{\mathrm{Sl}}$, which passes through a monothiolate intermediate, with distinct spectral features. In the present study we have used two site directed mutants of Sco ${ }^{\mathrm{SI}}, \mathrm{C} 86 \mathrm{~A}$ and C90A, to determine which Cys in the CXXXC motif acts as the capture ligand. Comparison of kinetic and thermodynamic parameters obtained from cupric ion binding to the C86A and C90A mutants clearly indicate that Cys86 is the capture ligand and this finding can be reconciled with structural data. At subsaturating levels of cupric ions both mutants bind copper rapidly, but the absorbance properties are distinctly different from wild type $\mathrm{Sco}^{\mathrm{SI}}$. This is most extreme for the C86A mutant where the Cys90 thiolate bond is considered to be weaker than the Cys86 thiolate bond in the C90A mutant. We put forward an explanation for this behaviour whereby we propose that the cupric ion is moving to a second site with no thiolate coordination.
\end{abstract}

Received 27th February 2013, Accepted 5th June 2013

DOI: $10.1039 / \mathrm{c} 3 \mathrm{dt} 50540 \mathrm{e}$ www.rsc.org/dalton
CXXXC motif for thioredoxin-like activity, rather than a $\mathrm{Cu}-$ metallochaperone. ${ }^{8}$ In the antibiotic producing Gram-positive bacteria, Streptomyces lividans, a Sco protein $\left(\mathrm{Sco}^{\mathrm{Sl}}\right)$ has been identified, the gene for which is part of an operon predicted to encode other cuproproteins that are likely to be involved in $\mathrm{Cu}$ handling in the extracellular environment. ${ }^{9,10}$ We have previously characterised $\mathrm{Sco}^{\mathrm{Sl}}$ and shown in vivo under low extracellular $\mathrm{Cu}(\mathrm{II})$ concentrations that it acts as a $\mathrm{Cu}$ (II)metallochaperone, supplying the co-factor to the $\mathrm{Cu}_{\mathrm{A}}$ site of COX. ${ }^{11}$ A second $\mathrm{Cu}(\mathrm{II})$-chaperoning role of $\mathrm{Sco}^{\mathrm{Sl}}$ to an as yet unidentified cuproenzyme has also been proposed and this latter function is essential for triggering a development switch in the life cycle of $S$. lividans that is concomitant with antibiotic production. ${ }^{11}$

All Sco proteins have a CXXXC motif, which regardless of their function has been shown in vitro to be redox active. ${ }^{11,12}$ From structural studies, only NMR has been successful in capturing a structure of a Sco protein with $\mathrm{Cu}$ bound at the correct site. ${ }^{13}$ The NMR structure of the $\mathrm{Cu}(\mathrm{I})$ bound form of human Sco1 $\left(\mathrm{Sco}^{\mathrm{h}}\right)$ reveals the two Cys residues in the CXXXC motif act as $\mathrm{Cu}(\mathrm{I})$-thiolate ligands, with a third ligand identified as a His-Ne2 atom completing the trigonal $\mathrm{Cu}(\mathrm{I})$ ion coordination geometry. ${ }^{13}$ A crystal structure of a Ni(II)-form of

\footnotetext{
${ }^{a}$ School of Biological Sciences, University of Essex, Wivenhoe Park, Colchester, CO4 3SQ, UK. E-mail: jworrall@essex.ac.uk; Tel: +44 (0) 1206872095

${ }^{b}$ Molecular Biotechnology, Institute of Biology Leiden, Sylvius Laboratory, Leiden University, PO Box 9505, 2300RA Leiden, The Netherlands

†Electronic supplementary information (ESI) available. See DOI 10.1039/c3dt50540e
} 
$\mathrm{Sco}^{\mathrm{h}}$ has also been reported and may be considered as a divalent surrogate for $\mathrm{Cu}$ (II). ${ }^{13}$ The coordination of the Ni(II) site also involves the Cys and His residues, with $\mathrm{a} \mathrm{Cl}^{-}$ion completing a distorted square planar geometry. In the apo-form, NMR studies with $\mathrm{Sco}^{\mathrm{h}}$ and Bacillus subtilis $\mathrm{Sco}\left(\mathrm{Sco}^{\mathrm{Bs}}\right)$ indicate that the $\mathrm{Cu}$ binding site is not pre-formed. ${ }^{13,14}$ In solution a large number of amino acid residues in the metal-binding region sample multiple local conformational states that interconvert with one another. This dynamic equilibrium places on average the coordinating His ligand $>10 \AA$ away from a S $\delta(\mathrm{Cys})$ atom in the CXXXC motif in $\mathrm{Sco}^{\mathrm{h}}{ }^{13}$ Thus considerable reorganisation of the protein loop housing the His ligand is required to form a compact $\mathrm{Cu}$ binding site. The X-ray structure of apo-Sco ${ }^{\mathrm{Bs}}$ corroborates the dynamic NMR data, ${ }^{6}$ with both Cys residues in the CXXXC motif located on a highly solvent exposed loop with the His ligand (His135) pointing away from the CXXXC loop and into solvent (Fig. 1). In contrast an unpublished X-ray structure of Bacillis anthracis $\mathrm{Sco}\left(\mathrm{Sco}^{\mathrm{Ba}}\right)$ shows high structural homology to the core Sco-fold of $\mathrm{Sco}^{\mathrm{Bs}}$ but a considerable variation in the loop regions housing the $\mathrm{Cu}$ binding ligands (Fig. 1). This structure now seemingly appears to be close to a preformed $\mathrm{Cu}$ binding site where both Cys residues in the CXXXC motif and the His ligand are turned inside the protein (Fig. 1). Thus these two structures serve to illustrate the flexibility in the $\mathrm{Cu}(\mathrm{II})$ binding site, with the core Sco-fold maintaining high structural similarity (Fig. 1).

Interest into the mechanisms of $\mathrm{Cu}(\mathrm{II})$ ions binding to flexible, dynamic regions in proteins has heightened in recent times with the discovery that $\mathrm{Cu}(\mathrm{II})$ ions readily bind to flexible motifs in $\alpha$-synuclein and amyloid- $\beta$ peptide, resulting in structural damage and thus a major role for $\mathrm{Cu}(\mathrm{II})$ ions in the

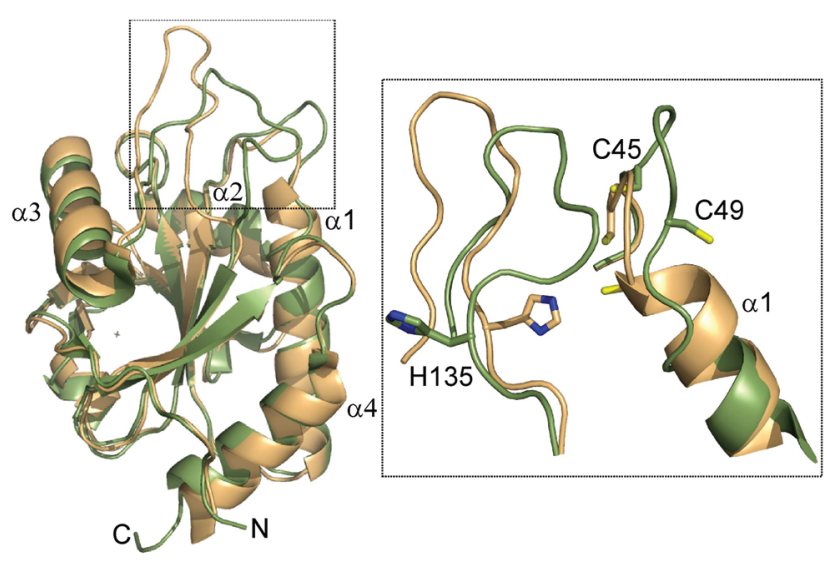

Fig. 1 Structure of bacterial Sco. An overlay of the X-ray crystal structures of the apo-Sco proteins from B. subtilis $(\mathrm{pdb} 1 \mathrm{XZO})^{6}$ green and B. anthracis (pdb $4 \mathrm{HDE}$ ) orange. The four $\alpha$-helices in the core thioredoxin fold are labelled along with the $\mathrm{N}$ - and C-termini with the loops containing the CXXXC motif and $\mathrm{Cu}(॥)$ His ligand indicted in the dashed box. Superposition of the two structures gives a root-mean-square-deviation (RMSD) in C $\alpha$ positions of the core Sco-fold (i.e. excluding the boxed loops) of $0.8 \AA$. A zoomed in region of the dashed box area highlights the positional differences between Cys and His residues in the two structures. Nitrogen and sulphur atoms are coloured blue and yellow, respectively. Residues are labelled with $\mathrm{Sco}^{\mathrm{Bs}}$ numbering which corresponds to Cys86 (C45), Cys90 (C49) and His176 (H135) in Sco ${ }^{\text {Sl. }}$ disease physiology of Parkinson's and Alzheimer's has been inferred. ${ }^{15-23}$ Furthermore, proteins involved in $\mathrm{Cu}$ trafficking and homeostasis pathways ${ }^{24-26}$ also rapidly bind $\mathrm{Cu}$ to cognate flexible binding motifs, with the kinetics of in vitro metallation studies indicative of intermediates and $\mathrm{Cu}(\mathrm{II})$-capture complexes with unusual ligand geometries and distinct absorbance spectrum. ${ }^{11,27-29}$ As part of a previous study the mechanism of $\mathrm{Cu}(\mathrm{II})$ capture and binding to $\mathrm{Sco}^{\mathrm{Sl}}$ along with the H176A mutant, where the coordinating His ligand has been replaced by an Ala, has been studied by UV-vis, EPR and stopped-flow spectroscopies. ${ }^{11}$ We developed a model where one of the Cys residues in the $\mathrm{CXXXC}$ motif is involved in initial $\mathrm{Cu}$ (II) capture. Therefore, to test further this model experimentally the aim of the present study is to determine which of the two Cys residues (Cys86 or Cys90) in the flexible CXXXC motif captures $\mathrm{Cu}$ (II) first, to yield a spectrally distinct $\mathrm{Cu}$ (II)-capture complex. We have employed two site-directed mutants, C86A and C90A, whereby each Cys residue in the CXXXC motif has been replaced in turn by an Ala residue, and we discuss the results in the context of our model. ${ }^{11}$

\section{Results and discussion}

\section{The Cys to Ala mutations in the CXXXC motif do not perturb the $\operatorname{Sco}^{\text {Sl }}$ fold}

From a previous study, the wild type (wt) $\mathrm{Sco}^{\mathrm{Sl}}$ and the H176A mutant were over-expressed in Escherichia coli and purified in the apo-form (i.e. no detectable $\mathrm{Cu}$ ions present). ${ }^{11}$ This was also the case in the present study with the C86A and C90A mutants. Far-UV circular dichroism (CD) spectroscopy of the two apo-Cys mutants gave almost identical spectra to that of the previously reported apo-wt $\mathrm{Sco}^{\mathrm{Sl}}$ with the spectral features consistent with a mixed secondary structure ${ }^{11}$ (Fig. 2). Dichroweb analysis ${ }^{30,31}$ confirmed that the Cys mutations do not significantly alter the percentage secondary structure content compared to wt $\mathrm{Sco}^{\mathrm{Sl}}$ (Table S1, ESI $\dagger$ ) and thus we conclude

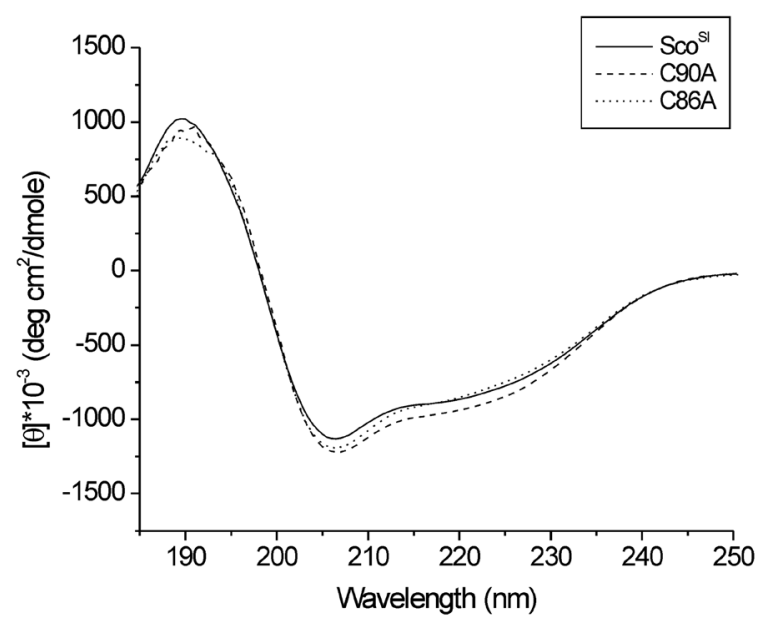

Fig. 2 Far UV-CD spectra of the apo-forms of wt Sco ${ }^{S 1}$ and the C86A and C90A mutants recorded at $20^{\circ} \mathrm{C}$ with protein concentrations $\sim 20 \mu \mathrm{M}$. 
that the Ala mutations in the CXXXC motif do not affect the overall structural fold.

\section{A model for $\mathrm{Cu}(\mathrm{II})$ binding to wt $\mathrm{Sco}^{\mathrm{SI}}$}

Fig. 3 depicts a model previously reported to account for $\mathrm{Cu}$ (II) binding to wt Sco ${ }^{\mathrm{Sl}}{ }^{11}$ Despite the absence of structural information for $\mathrm{Sco}^{\mathrm{Sl}}$ it is highly likely that the loops housing the His176 ligand and the CXXXC motif will be mobile and multiple conformations in equilibrium with one another will exist. Some of these we propose possess a pre-formed $\mathrm{Cu}$ (II) binding site (box in Fig. 3). The $\mathrm{Cu}(\mathrm{II})$ capture complex exists with coordination from an imidazolate $\mathrm{N}$ atom from His176, an unassigned $\mathrm{N}$-donor possibly from a nearby backbone amide, ${ }^{32}$ and a $\mathrm{Cu}(\mathrm{II})-$ monothiolate interaction from a Cys in the CXXXC motif (Fig. 3). In the wt $\mathrm{Sco}^{\mathrm{Sl}}$ rapid binding of $\mathrm{Cu}$ (II) to this initial site leads to the evolution of a broad absorbance band centred at $\lambda_{\max } \sim 375 \mathrm{~nm}$, that is assigned to arise from monothiolate $\mathrm{S}(\mathrm{Cys})-\mathrm{Cu}(\mathrm{II})$ coordination. The $\lambda_{\max }$ of this intermediate species is also modulated by the His176 ligand. ${ }^{11}$ A slower reorganisation of the protein brings the second available Cys residue in the CXXXC motif into the $\mathrm{Cu}(\mathrm{II})$ coordination sphere and leads to a 2 -fold increase in extinction coefficient $(\varepsilon)$ and a shift in $\lambda_{\max }$ to $\sim 362 \mathrm{~nm}$, which corresponds to that which we observe in the absorbance spectrum for the fully $\mathrm{Cu}$ (II) saturated $\mathrm{Sco}^{\mathrm{Sl}}$. The data with the $\mathrm{C} 86 \mathrm{~A}$ and
C90A mutants acquired in the present study have been interpreted based on this model (vide infra).

\section{Stoichiometric addition of $\mathrm{Cu}(\mathrm{II})$ to apo-C90A Sco ${ }^{\mathrm{SI}}$}

On addition of a stoichiometric amount of $\mathrm{Cu}$ (II) to the C90A mutant a number of distinct optical absorbance bands appear in the absorbance spectrum, with features consistent with those previously reported for wt $\mathrm{Cu}(\mathrm{II})-\mathrm{Sco}^{\text {Sl }}$ and other $\mathrm{Cu}(\mathrm{II})$ loaded Sco proteins ${ }^{11,33-35}$ (Fig. 4A). The major absorbance feature, with a $\lambda_{\max }$ between 360-380 nm depending on protein variant, is consistent with $\mathrm{S}(\mathrm{Cys})$-to-Cu(II) charge transfer interactions dominated by a favourable $\mathrm{Cu}(\mathrm{II})-\mathrm{Sp} \sigma$ interaction due to the $\mathrm{d} x^{2}-y^{2}$ orbital orientated in the equatorial plane. ${ }^{36}$ Weaker $\mathrm{Cu}(\mathrm{II})-\mathrm{Sp} \pi$ interactions are observed at lower energy (450-506 $\mathrm{nm}$ ) in the spectrum and d-d absorption at even lower energies (574-724 nm) are observed and are all consistent with a type- 2 tetragonally distorted $\mathrm{Cu}(\mathrm{II})$ site. ${ }^{37-39}$ The major absorbance band centred at $362 \mathrm{~nm}$ in the wt $\mathrm{Cu}$ (II)$\mathrm{Sco}^{\text {Sl }}$ is red shifted by $18 \mathrm{~nm}$ to $380 \mathrm{~nm}$ in the $\mathrm{Cu}(\mathrm{II})-\mathrm{C} 90 \mathrm{~A}$ protein, along with further significant red shifts for the two lower energy bands (Fig. 4A). Extinction coefficients $(\varepsilon)$ are also affected in the mutant, with the peaks at $380 \mathrm{~nm}\left(\varepsilon \sim 2400 \mathrm{M}^{-1}\right.$ $\left.\mathrm{cm}^{-1}\right)$ and $506 \mathrm{~nm}\left(\varepsilon \sim 463 \mathrm{M}^{-1} \mathrm{~cm}^{-1}\right)$ having a $\varepsilon$ of $c a$. half that of the corresponding peaks at $362 \mathrm{~nm}\left(\varepsilon \sim 4200 \mathrm{M}^{-1} \mathrm{~cm}^{-1}\right)$ and $459 \mathrm{~nm}\left(\varepsilon \sim 973 \mathrm{M}^{-1} \mathrm{~cm}^{-1}\right)$ in the wt $\mathrm{Sco}^{\text {Sl }}$. This may be

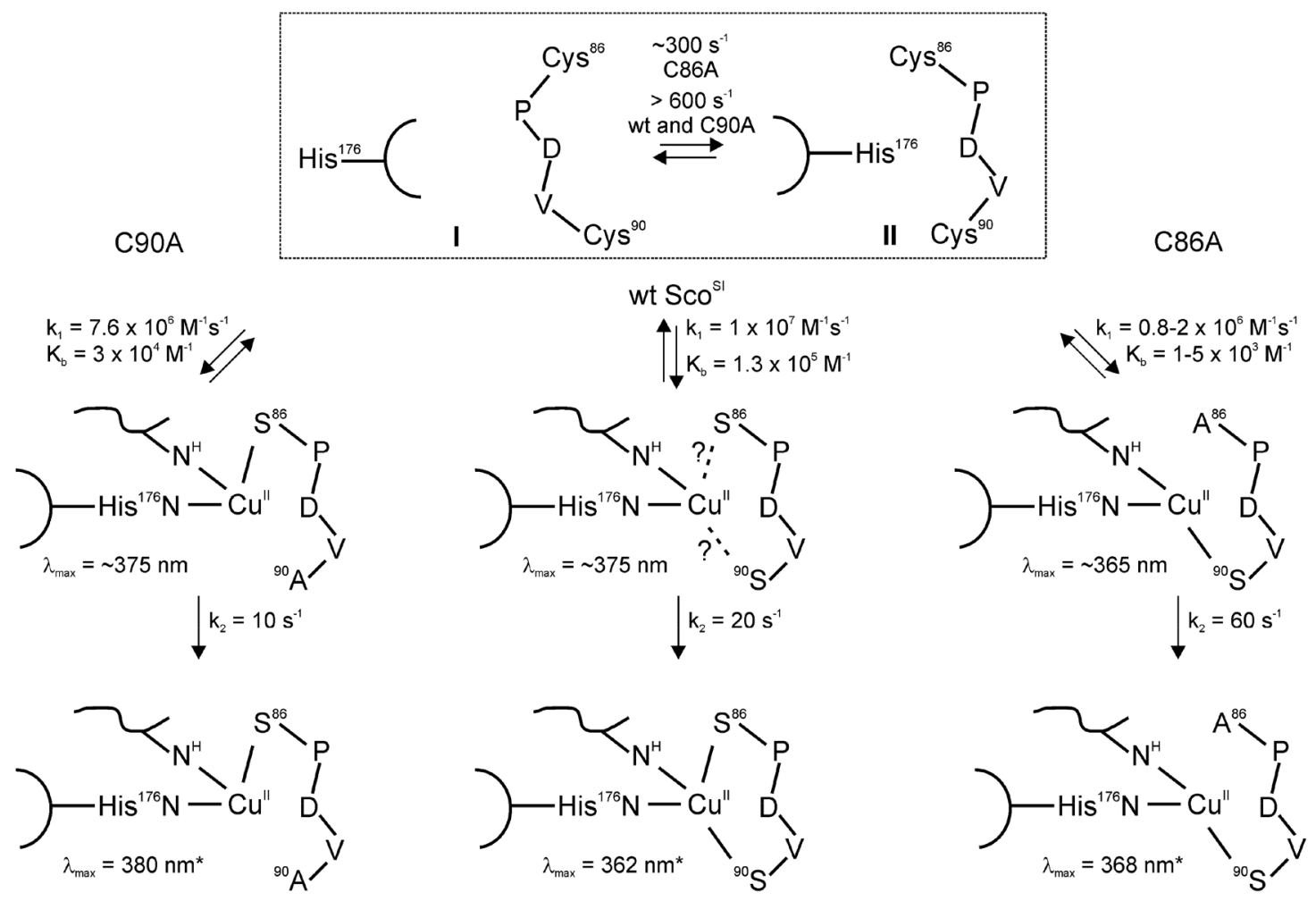

Fig. 3 Mechanistic features of Cu(II) binding to the Cys-X-X-X-Cys motif (Cys-Pro-Asp-Val-Cys) in Sco ${ }^{\text {SI }}$ and the two Cys mutants C86A and C90A as discussed in detail in the main text. Species I and II in the box are representative of the disordered and preformed $\mathrm{Cu}(\boldsymbol{I})$ binding sites, respectively, and the ? symbolises the unknown identity of the Cys residue involved in the initial $\mathrm{Cu}(\|)$ capture complex, prior to the studies with the Cys mutants. Some kinetic $\left(k_{1}\right.$ and $\left.k_{2}\right)$ and thermodynamic $\left(K_{\mathrm{b}}\right)$ parameters are reported along with $\lambda_{\max }$ of intermediate species determined from stopped-flow experiments and $\lambda_{\max }$ of the final $\mathrm{Cu}\left({ }^{\prime \prime}\right)$-bound species $\left({ }^{*}\right)$ determined by UV-vis spectroscopy. 
A

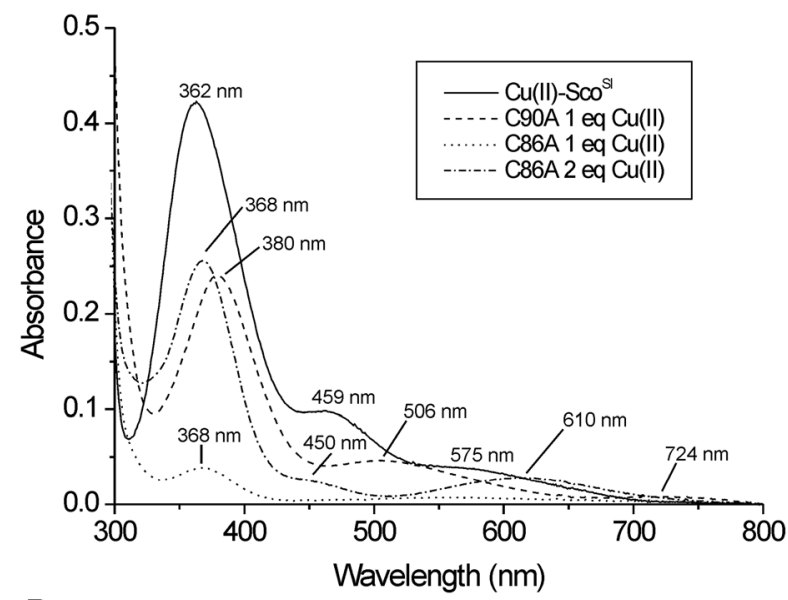

B

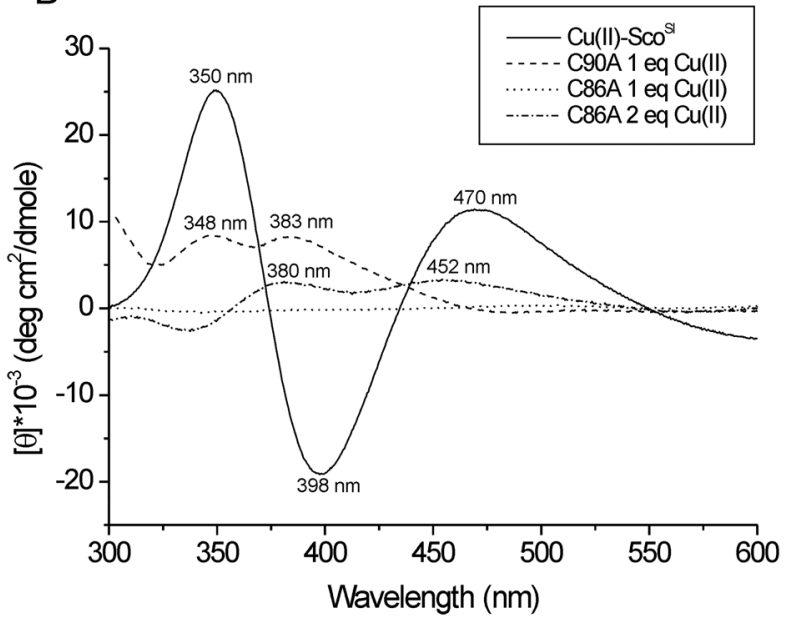

Fig. 4 Absorbance and visible CD spectra. (A) Absorbance spectrum of $\mathrm{Cu}(\mathrm{II}$ $\mathrm{ScO}^{\mathrm{Sl}}, \mathrm{Cu}(1)-\mathrm{C} 86 \mathrm{~A}$ and $\mathrm{Cu}(I)-\mathrm{C} 90 \mathrm{~A}$ at $20{ }^{\circ} \mathrm{C} \mathrm{pH}$ 7.5. The spectrum of the $\mathrm{Cu}(1)-$ $\mathrm{SCO}^{\mathrm{SI}}$ is taken after addition of one equivalent of $\mathrm{Cu}\left(\mathrm{II}^{1}{ }^{11}\right.$ as is also the case for the C90A mutant. Spectrum taken following the addition of one and two $\mathrm{Cu}($ II) equivalents to the C86A mutant are also shown. The differences in $\lambda_{\max }$ between proteins are indicated. (B) Visible $\mathrm{CD}$ spectra of $\mathrm{Cu}(\|)-\mathrm{ScO}{ }^{\mathrm{Sl}}, \mathrm{Cu}(\mathrm{II})-\mathrm{C} 86 \mathrm{~A}$ and $\mathrm{Cu}(11)-\mathrm{C} 90 \mathrm{~A}$ at $20{ }^{\circ} \mathrm{C} \mathrm{pH}$ 7.0. The wt and $\mathrm{C} 90 \mathrm{~A}$ mutant spectra were recorded following addition of one $\mathrm{Cu}(I)$ equivalent and the C86A following addition of one and two equivalents of $\mathrm{Cu}(I)$. The $\lambda_{\max }$ for the major peaks are indicated.

expected for a wt spectrum dominated by cysteinyl ligation. The $\lambda_{\max }$ at $380 \mathrm{~nm}$ for the $\mathrm{C} 90 \mathrm{~A} \mathrm{Cu}(\mathrm{II})$-loaded mutant is identical to that of the C49A mutant of $\mathrm{Sco}^{\mathrm{Bs}}$ (equivalent to C90A) ${ }^{40}$ and also similar to the $\lambda_{\max }$ of $\sim 375 \mathrm{~nm}$ for an intermediate species determined for wt $\mathrm{Sco}^{\mathrm{Sl}}$ by kinetics studies, that was attributed to an initial $\mathrm{Cu}(\mathrm{II})$ capture complex with a single coordinating Cys residue $^{11}$ (Fig. 3). The saturated Cu(II)-C90A spectrum remained stable under aerobic conditions for $>24 \mathrm{~h}$, with no evidence for autoreduction, as has previously been reported on removing the His ligand in $\mathrm{Sco}^{\mathrm{Sl}}$ and $\mathrm{Sco}^{\mathrm{Bs}}$ and in the C49A mutant of $\mathrm{Sco}^{\mathrm{Bs}} \cdot{ }^{11,40,41}$ In conjunction with the absorbance spectrum, a visible $\mathrm{CD}$ spectrum of $\mathrm{Cu}$ (II)-C90A was acquired (Fig. 4B). It is apparent from comparison with wt $\mathrm{Cu}(\mathrm{II})-\mathrm{Sco}^{\mathrm{Sl}}$ that the visible $\mathrm{CD}$ spectrum is also dominated by cysteinyl ligation, with large spectral changes in both wavelength and intensity being observed in the mutant (Fig. 4B).

\section{Kinetics of $\mathrm{Cu}$ (II) binding to the apo-C90A mutant}

Kinetics studies were conducted under first order or quasi-first order conditions i.e. those in which [Cu(II)] is in excess over the protein. On mixing either the C90A or the C86A mutant with an excess of $\mathrm{Cu}$ (II), a very rapid spectral change was observed between 320-420 $\mathrm{nm}$. Biphasic time courses were obtained for both mutants over this spectral range, but unlike the wt protein the second slower phase was very small in amplitude compared to that of the faster process. Fig. 5A illustrates time courses of the first rapid phase at $380 \mathrm{~nm}$ for the C90A mutant, where it may be observed after an initial flow period lasting $\sim 1.5 \mathrm{~ms}$ the kinetics of $\mathrm{Cu}$ (II) binding may be discerned. The observed portion of the time course may be fit to a single exponential and the rate constant $\left(k_{1 \_ \text {C90A }}\right)$ of this process is $[\mathrm{Cu}(\mathrm{II})]$ dependent. Because the process is so fast for the stopped-flow method, only a portion of the time course is observed, but it is satisfying that the exponential fits between 1.5 and $20 \mathrm{~ms}$ all extrapolate back to the same absorbance at $t=0$ and to the same asymptotic absorbance value at $t=20 \mathrm{~ms}$ (Fig. 5A). The rate constants at a number of $[\mathrm{Cu}(\mathrm{II})]$ derived from global fitting of the data are plotted in Fig. $5 \mathrm{~B}$ as are the rate constants for the small slow process $\left(k_{2}\right.$ C90A $)$. The second order rate constant $\left(k_{1}\right)$ for the first $\mathrm{Cu}(\mathrm{II})$ binding phase in the C90A mutant, was $7.6(0.6) \times 10^{6} \mathrm{M}^{-1} \mathrm{~s}^{-1}$, close to $1 \times 10^{7} \mathrm{M}^{-1} \mathrm{~s}^{-1}$ reported for wt Sco ${ }^{\mathrm{Sl}} .{ }^{11}$ The off-rate $\left(k_{-1}\right)$ was estimated to be $250 \mathrm{~s}^{-1}$, faster than the wt $\mathrm{Sco}^{\mathrm{Sl}}$ and results in an equilibrium binding constant $\left(K_{\mathrm{b}}=k_{1} / k_{-1}\right)$ for the initial binding site of $\sim 3.0 \times 10^{4} \mathrm{M}^{-1}$, somewhat lower than the value of $1.3 \times 10^{5}$ $\mathrm{M}^{-1}$ for wt Sco ${ }^{\mathrm{Sl}}$ and the H176A mutant $\left(K_{\mathrm{b}}=6.7 \times 10^{4} \mathrm{M}^{-1}\right)^{11}$ (see Fig. 3). The wavelength dependence of the amplitudes for the fast phase are shown in Fig. 6B, where it is compared with wt Sco ${ }^{\mathrm{Sl}}$, taken under similar conditions (Fig. 6A) ${ }^{11}$ It is apparent that the spectral distribution of the fast phase for both proteins is similar, with a $\lambda_{\max }$ of $\sim 375 \mathrm{~nm}$ for the C90A mutant, indicating that the thiolate of Cys86 binds in the C90A mutant as it does in the wt $\mathrm{Sco}^{\mathrm{Sl}}$. The rate constant for the second, $[\mathrm{Cu}(\mathrm{II})]$ independent step $\left(k_{2 \_\mathrm{C} 90 \mathrm{~A}}\right)$ is $10(2) \mathrm{s}^{-1}$, and is of the same order of magnitude as that seen in wt $\mathrm{ScO}^{\mathrm{Sl}}, k_{2}=20 \mathrm{~s}^{-111}$ (Fig. 3). However, the amplitude and thus spectral contribution to the overall optical change is considerably smaller than seen in wt $\mathrm{Sco}^{\mathrm{Sl}}$ as also observed in the static spectrum (Fig. 4A). This may be appreciated from inspection of Fig. 6B, where the spectra of the two phases of $\mathrm{Cu}(\mathrm{II})$ binding for the C90A protein are shown in comparison to those observed in wt $\mathrm{Sco}^{\text {Sl }}$ (Fig. 6A). We have rationalised these results, as shown in Fig. 3, by proposing that the initial binding of $\mathrm{Cu}(\mathrm{II})$ to $\mathrm{ScO}^{\mathrm{Sl}}$ is to a site with rapid monothiolate coordination of S(Cys86)-to$\mathrm{Cu}$ (II), thereafter, in the wt $\mathrm{Sco}^{\mathrm{Sl}}$, a rearrangement of this site occurs enabling the coordination of the Cys90. When this second thiol is unavailable, as in the C90A mutant, the reorganisation of the site, although leading to some spectral change, cannot lead to the full spectral development and the 

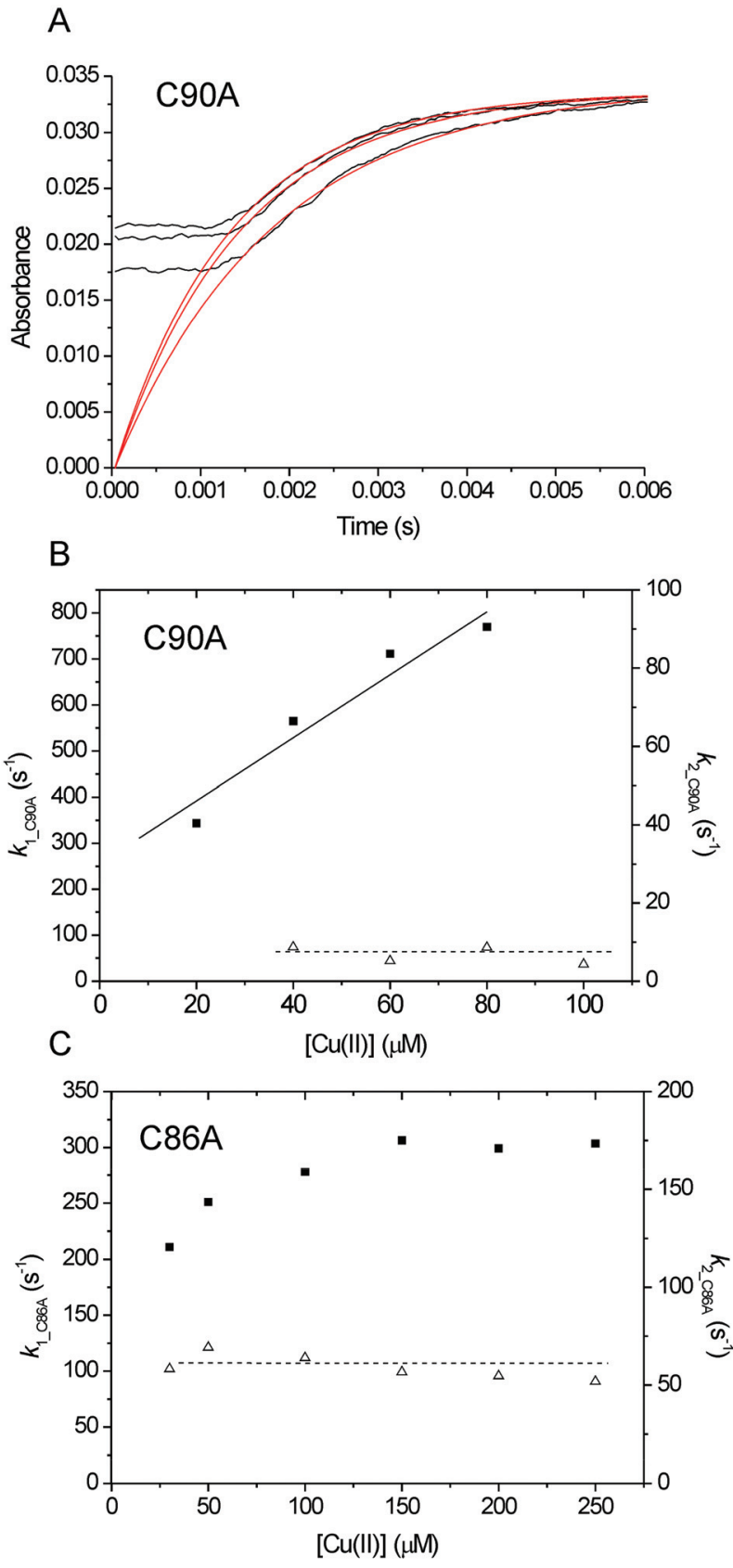

Fig. 5 Stopped-flow kinetics of $\mathrm{Cu}(\|)$ binding to the Cys mutants of $\mathrm{ScO}^{\mathrm{Sl}}$. (A) Examples of time courses at $380 \mathrm{~nm}$ and $20^{\circ} \mathrm{C}$, with fits to an exponential function (red line), on reacting $15 \mu \mathrm{M}$ of $\mathrm{C} 90 \mathrm{~A}$ with 40,60 and $80 \mu \mathrm{M}$ of $\mathrm{Cu}(\mathrm{II})$. Firstorder rate constants for the fast ( $k_{1}$; filled squares) and slow (not shown in the time course) ( $k_{2}$; open triangles) phases of $\mathrm{Cu}(I)$ binding to the C90A (B) and C86A (C) mutants of Sco ${ }^{\mathrm{Sl}}$. The solid line in the C90A plot indicates a fit to the first rapid phase $\left(k_{1}\right)$ to obtain a second-order rate constant and the dashed line indicates the independence of the rate of the slower phase $\left(k_{2}\right)$ on $\left[\mathrm{Cu}\left({ }^{\prime \prime}\right)\right]$.

fully saturated C90A mutant resembles the intermediate of the wt Sco $^{\text {Sl }}$ with Cys86 bound (Fig. 3).

\section{Stoichiometric addition of $\mathrm{Cu}$ (II) to the apo-C86A mutant}

Addition of a stoichiometric amount of $\mathrm{Cu}$ (II) to the C86A mutant gave an initial optical spectrum with weak intensity
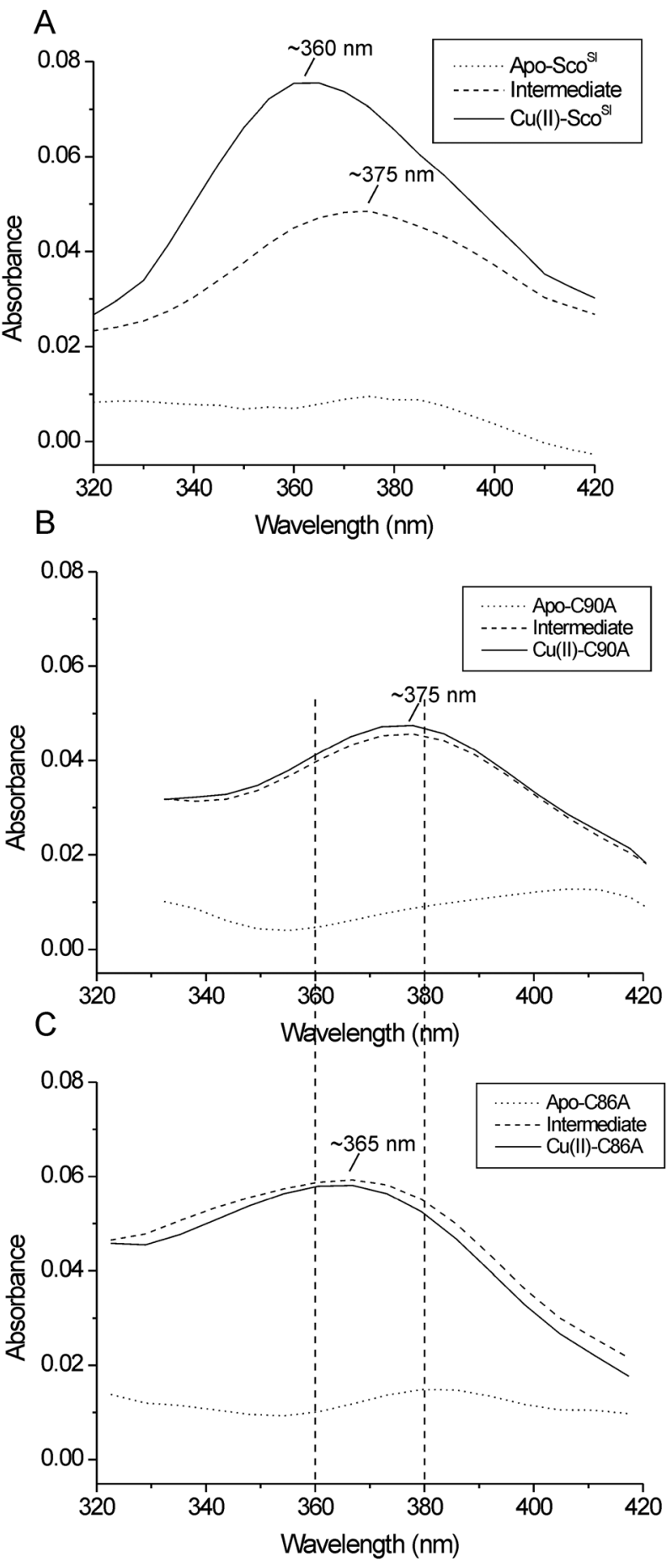

Fig. 6 Comparison of intermediate and final spectra for $\mathrm{Cu}(॥)$ binding to Sco ${ }^{\mathrm{Sl}}$ and mutants determined from stopped-flow spectroscopy. In (A) wt Sco ${ }^{\mathrm{SI}},(B)$ C90A and (C) C86A, are the spectra obtained from the global fitting of the time course kinetic data recorded between 320 and $420 \mathrm{~nm}$ to the model apo > intermediate $>$ final $\mathrm{Cu}(\|)$ bound species. The $\lambda_{\max }$ for the intermediate and final form of the wt $\mathrm{Sco}^{\mathrm{Sl}}$ and the two mutants are indicated.

absorption bands compared to wt $\mathrm{Sco}^{\mathrm{Sl}}$ and the C90A mutant (Fig. 4A). However, on addition of a second $\mathrm{Cu}(\mathrm{II})$ equivalent the absorption bands intensify (Fig. $4 \mathrm{~A}$ ) and a $6 \mathrm{~nm}$ red shift 
in $\lambda_{\max }$ for the major absorbance band to $368 \mathrm{~nm}$ occurs along with a prominent red shifted $\mathrm{d}-\mathrm{d}$ transition compared to wt $\mathrm{Cu}(\mathrm{II})-\mathrm{Sco}^{\mathrm{Sl}}$ (Fig. 4A). The peak at $368 \mathrm{~nm}$ has an $\varepsilon$ of $\sim 2560 \mathrm{M}^{-1} \mathrm{~cm}^{-1} \mathrm{ca}$. half that of the corresponding peak at $365 \mathrm{~nm}\left(\varepsilon \sim 4200 \mathrm{M}^{-1} \mathrm{~cm}^{-1}\right)$ in wt $\mathrm{Sco}^{\mathrm{Sl}}$, again consistent with monothiolate $\mathrm{Cu}(\mathrm{II})$ coordination. The $\mathrm{Cu}(\mathrm{II})-\mathrm{Sp} \pi$ absorption band at $450 \mathrm{~nm}$ is slightly blue shifted relative to both wt and C90A proteins and has an $\varepsilon\left(255 \mathrm{M}^{-1} \mathrm{~cm}^{-1}\right)$ that is $c a$. half that of the C90A mutant and $\sim 3.5$ times less than $\mathrm{Cu}(\mathrm{II})-\mathrm{Sco}^{\mathrm{Sl}}$. This has the effect of significantly altering the $\mathrm{Sp} \sigma / \mathrm{Sp} \pi$ ratio of the $\mathrm{S}$ (Cys)-to-Cu(II) charge transfer interaction determined for Sco proteins from the $\varepsilon_{350} / \varepsilon_{450}$ ratio. ${ }^{5,41}$ For $\mathrm{Cu}(\mathrm{II})$-loaded $\mathrm{Sco}^{\mathrm{Bs}}$ a $\varepsilon_{350} / \varepsilon_{450}$ ratio of 4.6 has been reported, ${ }^{41}$ which is similar to values of 4.3 and 5.1 for wt $\mathrm{Cu}(\mathrm{II})-\mathrm{Sco}^{\mathrm{Sl}}$ and the C90A mutant, respectively, whereas for the C86A mutant a ratio of $\sim 10$ is observed. This suggests that the S(Cys90)-to-Cu(II) interaction in the C86A mutant has a more favourable Spo overlap which can indicate a longer $\mathrm{Cu}-\mathrm{S}(\mathrm{Cys})$ bond length or a lower degree of covalency than the S(Cys86)-to-Cu(II) interaction in the C90A mutant. Differences in the degree of covalency between the two thiolates in $\mathrm{Sco}^{\mathrm{Bs}}$ have been inferred form EPR and EXAFS studies. ${ }^{40}$ The visible CD-spectrum of the C86A mutant with 2 equivalents of $\mathrm{Cu}(\mathrm{II})$ is clearly different form the C90A and the wt protein (Fig. 4B). The peak maxima for the C86A mutant are significantly wavelength shifted with respect to the C90A mutant and the wt Sco ${ }^{\text {Sl }}$. Therefore, this may be considered as further evidence to suggest that S(Cys)-Cu(II) thiolate bonds differ in bonding properties that influence the electronic properties of the $\mathrm{Cu}(\mathrm{II})$ site.

\section{Kinetics of $\mathrm{Cu}(\mathrm{II})$ binding to the apo-C86A mutant}

Under pseudo-first order conditions the initial $\mathrm{Cu}(\mathrm{II})$ binding to the C86A mutant was slower than seen in the C90A mutant, and the observed pseudo-first order rate constant ( $\left.k_{1 \_ \text {C86A }}\right)$ approached a rate limit at around $300 \mathrm{~s}^{-1}$ (Fig. 5C). From the initial portion of a plot of $k_{\text {obs }}$ (between 10-150 $\mu \mathrm{M} \mathrm{Cu(II)),} \mathrm{an}$ apparent $k_{1}$ for $\mathrm{Cu}$ (II) binding may be estimated to lie between 0.8 and $2(0.3) \times 10^{6} \mathrm{M}^{-1} \mathrm{~s}^{-1}$. An estimate for $k_{-1}$ of $\sim 150 \mathrm{~s}^{-1}$ yields a $K_{\mathrm{b}}$ value between $1-5 \times 10^{3} \mathrm{M}^{-1}$, significantly lower than both wt Sco ${ }^{\mathrm{Sl}}$ and the C90A mutant (Fig. 3). The spectral change that accompanies this initial process is shown in Fig. 6C, where it is seen that this spectrum is again indicative of monothiolate coordination in terms of $\varepsilon$ but the $\lambda_{\max }$ of $\sim 365 \mathrm{~nm}$ differs from wt $\mathrm{Sco}^{\mathrm{Sl}}$ under the same conditions $\left(50 \mu \mathrm{M} \mathrm{Cu}(\mathrm{II})+15 \mu \mathrm{M}\right.$ protein after mixing). ${ }^{11}$ Furthermore, the kinetics are significantly different from wt $\mathrm{Sco}^{\mathrm{Sl}}$ and the C90A mutant. We account for these differences by proposing that in the absence of Cys86, i.e. the thiol that we suggest binds first, the Cys90 binds but in this case the site is more difficult to form and the rate of this formation is rate limited at $300 \mathrm{~s}^{-1}$ (Fig. 5C). We have observed a similar rate limiting step for $\mathrm{Cu}$ (II) binding $\left(170 \mathrm{~s}^{-1}\right)$ in the $\mathrm{H} 176 \mathrm{~A}$ mutant and have explained this in terms of the rate of which the $\mathrm{Cu}$ (II) binding site forms ${ }^{11}$ (box Fig. 3). As binding is proceeded by two (classes of) conformers, only one of which binds $\mathrm{Cu}(\mathrm{II})$, then, under conditions when $\mathrm{Cu}(\mathrm{II})$ binding is slower than the conformational rearrangement and the binding form is initially at low concentrations compared to the disordered form, the $k_{1}$ is lowered by a factor of $K_{\mathrm{b}} /\left(1+K_{\mathrm{b}}\right)$, [binding form $] /\left[\right.$ non-binding form] . Thus the lower apparent $k_{1}$ for C86A indicates that the equilibrium between the conformers is between 10-20 fold less favourable for binding $\mathrm{Cu}$ (II) than in the C90A mutant. The second slower [Cu(II)] independent phase, $k_{2} \sim 60$ (2) $\mathrm{s}^{-1}$ (Fig. 5C), as seen for C90A was of a small amplitude contributing little to the overall spectral change (Fig. 6C).

\section{Sub-stoichiometric Cu(II) titrations to apo-C86A and C90A Sco ${ }^{\text {Sl }}$ mutants}

At sub-stoichiometric ratios of $\mathrm{Cu}$ (II) to protein the behaviour of the C86A and C90A mutants are quite different to that previously observed for wt $\mathrm{Sco}^{\mathrm{Sl}}$ and the H176A mutant. ${ }^{11}$ This was already hinted at by the requirement of an excess of $\mathrm{Cu}$ (II) to stabilise the C86A mutant absorbance spectrum (Fig. 4A). For the C86A mutant $\sim 0.8$ equivalent of $\mathrm{Cu}$ (II) is required before an optical change in the spectrum at $368 \mathrm{~nm}$ is observed, with further addition of $\mathrm{Cu}$ (II) leading to a linear increase in the absorbance at $368 \mathrm{~nm}$ before reaching a plateau at a $\mathrm{Cu}(\mathrm{II})$ : protein ratio of $1.5: 1$ (Fig. 7A inset). From stopped-flow experiments with the C86A mutant, sub-stoichiometric ratios of $\mathrm{Cu}$ (II) to protein, displayed behaviour shown in Fig. 7B, where an initial fast increase at $380 \mathrm{~nm}$, indicating monothiolate binding to $\mathrm{Cu}(\mathrm{II})$, gives way to a rapid decrease in the absorbance, which at subsaturating $\mathrm{Cu}(\mathrm{II})$ : protein ratios $(0.75: 1)$ fully abolishes the initial increase. At a $\mathrm{Cu}(\mathrm{II})$ : protein ratio of $3: 1$ or $6: 1$, the decrease is absent (Fig. 7B). This behaviour is thus consistent with the static titration data for the C86A mutant where below stoichiometric $\mathrm{Cu}$ (II) the overall absorbance change at $362 \mathrm{~nm}$, taken approximately $1 \mathrm{~min}$ after the $\mathrm{Cu}$ (II) addition is very small, if at all detectable. In the case of the C90A mutant stopped-flow reveals only a slight absorbance decrease compared to the C86A mutant at similar sub-stoichiometric $\mathrm{Cu}(\mathrm{II})$ ratios, consistent with the shorter 'lag phase' for optical change in the static experiment (Fig. 7A).

As mentioned previously, mutations to the $\mathrm{Cu}$ ligands in $\mathrm{Sco}^{\mathrm{Sl}}$ and $\mathrm{Sco}^{\mathrm{Bs}}$ have been shown to cause instability in the $\mathrm{Cu}(\mathrm{II})$ coordination sphere increasing the susceptibility of the $\mathrm{Cu}(\mathrm{II})$ bound form to autoreduce to $\mathrm{Cu}(\mathrm{I}) .^{11,40,42}$ Thus to account for our spectroscopic observations one suggestion is that on addition of sub-stoichiometric amounts of $\mathrm{Cu}$ (II) to the C86A mutant, $\mathrm{Cu}$ (II) binds rapidly as indicated from stoppedflow spectroscopy (Fig. 7B), and then becomes reduced to $\mathrm{Cu}(\mathrm{I})$. Although, the source of these reducing equivalents is unknown, it has been documented by several groups working on $\mathrm{Cu}$ chaperones and regulators that aerobic addition to samples of $\mathrm{Cu}(\mathrm{II})$ ions rapidly leads to the $\mathrm{Cu}(\mathrm{I})$-bound form. ${ }^{43-46}$ Subsequent additions of $\mathrm{Cu}(\mathrm{II})$ to the $\mathrm{C} 86 \mathrm{~A}$ mutant may oxidise the $\mathrm{Cu}(\mathrm{I})$ bound site to form the spectrum in Fig. $4 \mathrm{~A}$ at high [Cu(II)], leading to the titration data we report in the inset to Fig. 7A. However, this argument may be difficult to sustain given the relative redox potentials of $\mathrm{Cu}(\mathrm{II})$ in 
A

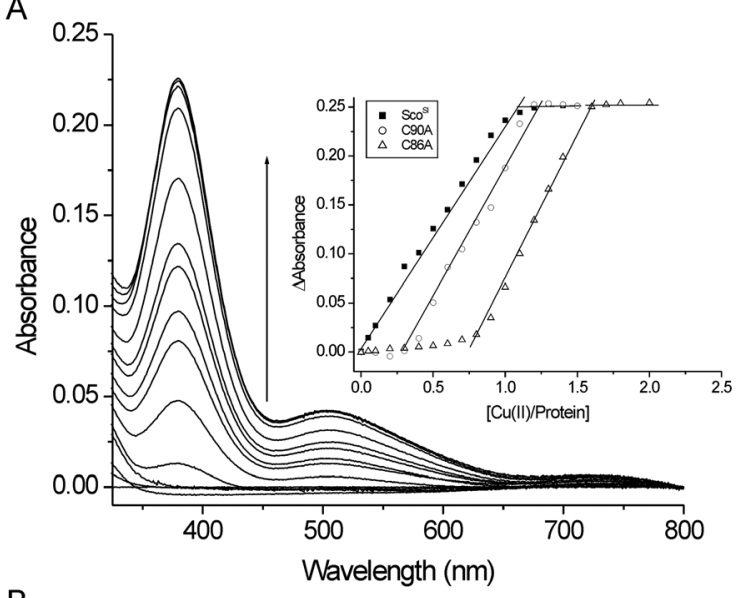

B

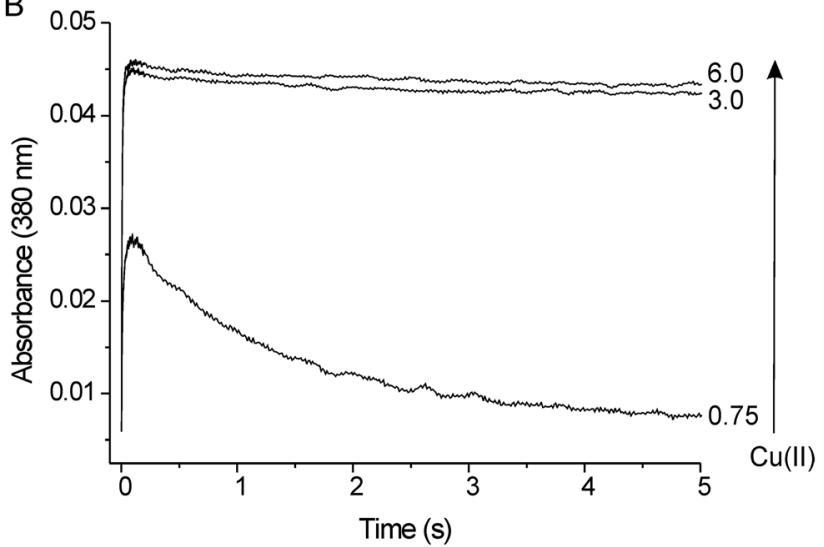

Fig. 7 Sub-stoichiometric addition of $\mathrm{Cu}(\Perp)$. (A) Evolution of absorbance spectra for the C90A mutant upon addition of increasing [Cu(॥)] (0-150 $\mu \mathrm{M}$ of $\mathrm{Cu}\left({ }^{\prime}\right), \sim 100 \mu \mathrm{M}$ of protein). Inset, changes in absorbance at $\lambda_{\max } 362 \mathrm{~nm}$, $380 \mathrm{~nm}$ and $368 \mathrm{~nm}$ for wt Sco ${ }^{\mathrm{Sl}}, \mathrm{C90A}$ and C86A, respectively, plotted as a function of $[\mathrm{Cu}(॥) /[$ protein]. (B) Stopped-flow time courses at $380 \mathrm{~nm}$ observed on reacting $15 \mu \mathrm{M}$ of C86A with $0.75,3.0$ and 6.0 equivalents of $\mathrm{Cu}(\Perp)$.

solution and the $\mathrm{Cu}(\mathrm{I})$ bound in the site, and therefore an alternative mechanism may be worthy of consideration. We therefore suggest, that in the C86A mutant initial binding of $\mathrm{Cu}$ (II) to the thiol is followed by a rearrangement that releases $\mathrm{Cu}$ (II) from this coordination. Fluorescence data (not shown) indicates $\mathrm{Cu}$ remains bound to the protein, thus $\mathrm{Cu}$ must be relocated to a second site that does not permit thiol binding, yet still quenches the fluorescence of the Trp at position 132 in $\mathrm{Sco}^{\mathrm{Sl}}$. Once this site is filled, subsequent $\mathrm{Cu}(\mathrm{II})$ ions bind to the thiol and now cannot move to the second occupied site and thus the titration and kinetic experiments conform more closely to the wt $\mathrm{Sco}^{\mathrm{Sl}}$. In support of this argument the crystal structure of the yeast Sco protein reveals that $\mathrm{Cu}(\mathrm{II})$ is capable of binding at a site with its cognate His ligand, equivalent to His176 in Scosl, but not involving the Cys residues from the CXXXC motif. ${ }^{47}$ Future work could employ EPR and paramagnetic NMR spectroscopy techniques to study binding of subsaturating $[\mathrm{Cu}(\mathrm{II})]$ with the $\mathrm{C} 86 \mathrm{~A}$ mutant to provide further evidence to corroborate a second $\mathrm{Cu}(\mathrm{II})$ site as inferred here from kinetic studies.

\section{Concluding remarks}

The results reported of investigations using two site directed mutants (C86A and $\mathrm{C} 90 \mathrm{~A})$ of $\mathrm{Sco}^{\mathrm{Sl}}$ support the earlier model proposed for $\mathrm{Cu}$ (II) binding to $\mathrm{Sco}^{\mathrm{Sl}}$, whereby initial binding of $\mathrm{Cu}(\mathrm{II})$ to a single Cys residue is followed by a reorganisation step leading to binding of a second available Cys. ${ }^{11}$ Furthermore, the data show that the initial binding involves Cys86, with subsequent Cys90 binding required for the rearrangement step. This conclusion is strongly supported by the initial binding of $\mathrm{Cu}(\mathrm{II})$ to the C90A mutant being closely similar in kinetic and thermodynamic parameters to the wt $\mathrm{Sco}^{\mathrm{Sl}}$, whereas the C86A mutant yields both binding and thermodynamic parameters that differ significantly (Fig. 3). A reason why Cys86 is the preferred capture residue in $\mathrm{Sco}^{\mathrm{Sl}}$ may find an explanation from the structures depicted in Fig. 1. If we assume that the structure of $\mathrm{Sco}^{\mathrm{Ba}}$ represents an apo-conformer with a semi-preformed $\mathrm{Cu}(\mathrm{II})$ site then the second Cys in the CXXXC motif (Cys90 in $\mathrm{Sco}^{\mathrm{Sl}}$ ) is now locked down into ahelix-1. Cys86 on the other hand remains in a loop segment and therefore retains freedom to sample different orientations enabling $\mathrm{Cu}(\mathrm{II})$ capture and transfer into the site. As may be expected from this model the full saturation of the two mutant proteins generate spectra that are closely similar to the intermediate formed in the wt $\mathrm{Sco}^{\mathrm{Sl}}$, in which only one $\mathrm{Cu}(\mathrm{II})$-thiolate bond is formed. These conclusions are summarised schematically in Fig. 3. The details of the spectra, along with the visible $\mathrm{CD}$ spectra yield interesting information about differences in the thiolate $\mathrm{Cu}(\mathrm{II})$ coordination that is apparent between the two Cys in the CXXXC motif. In particular the C86A spectrum is consistent with the $\mathrm{Cu}(\mathrm{II})-\mathrm{S}$ (Cys90) having lower covalency, giving some credence to the argument regarding the movement of $\mathrm{Cu}(\mathrm{II})$ to a second site at subsaturating $[\mathrm{Cu}(\mathrm{II})]$. Furthermore, it is very much apparent for both mutants, but in particular the C86A mutant, that removing one thiol by mutagenesis renders the site much more labile and prone to secondary reactions that complicate full analysis of a binding mechanism. Notwithstanding these complexities the main conclusions given above regarding $\mathrm{Cu}$ (II) binding to the CXXXC motif remain secure.

\section{Experimental}

Site-directed mutagenesis and over-expression of the C86A and C90A Sco ${ }^{\text {S1 }}$ mutants

The Quikchange (Stratagene) site directed mutagenesis method was employed to create the C86A and C90A mutations in $\mathrm{Sco}^{\mathrm{Sl}}$ using the following mutagenic primer pairs, with the nucleotides changed to create the respective mutation shown in lower case; C86A-F, 5'-CTTCGGCTACACCCACgcCCCCGACGTCTG-3'，C86A-R 5'-CAGACGTCGGGGgcGTGGGTGTAGCCGAAG-3', C90A-F 5'-GCCCCGACGTCgcCCCGCTGACCATGAAC-3', C90A-R 5'-GTTCATGGTCAGCGGGgcGACGTCGGGGC-3'. Confirmation of mutant clones was corroborated from DNA sequencing. Over-expression in BL21(DE3) Escherichia coli cells 
and subsequent purification of the C86A and C90A $\mathrm{Sco}^{\mathrm{Sl}}$ mutants was carried out as previously described for the wt Sco ${ }^{\text {Sl }}{ }^{11}$ The purified mutants were subjected to denaturing Electrospray ionisation mass spectrometry (ESI-MS) using a Micromass Quattro Ultima triple quadrupole instrument operating in the positive ion detection mode. A mass of $21235 \pm$ 1.3 Da was obtained for the C90A and C86A mutants, with the predicted mass calculated to be 21233 Da.

\section{Circular dichroism spectroscopy}

Concentrations of proteins were determined by UV-Visible spectroscopy (Varian Cary 50 UV-visible spectrophotometer) using an $\varepsilon$ of $14440 \mathrm{M}^{-1} \mathrm{~cm}^{-1}$ at $280 \mathrm{~nm}$. Protein samples $(20 \mu \mathrm{M})$ for $\mathrm{CD}$ analysis were exchanged into $10 \mathrm{mM} \mathrm{KPi}$, $50 \mathrm{mM} \mathrm{KF}, \mathrm{pH} 7.0$ and far UV- and visible-CD spectra were recorded between 260 and $175 \mathrm{~nm}$ and 600 and $300 \mathrm{~nm}$, respectively, at $20{ }^{\circ} \mathrm{C}$ on an Applied Photophysics Chirascan CD spectrophotometer (Leatherhead, UK) equipped with a thermostatic cell holder controlled with a Peltier system. CD spectra were analysed using Dichroweb ${ }^{30,31}$ with the programs $\operatorname{CDSSTR}^{48-50}$ and Contin-LL ${ }^{51}$ and the databases $1,3,4,6$, $7^{50,52}$ and SP175. ${ }^{53}$

\section{Cu(II) titrations monitored by UV-vis spectroscopy}

Prior to $\mathrm{Cu}$ (II) binding experiments, the C86A and the C90A $\mathrm{Sco}^{\mathrm{Sl}}$ proteins were exchanged into $20 \mathrm{mM}$ sodium phosphate, $50 \mathrm{mM} \mathrm{NaCl}, \mathrm{pH} 7.5$ solution by passing through a PD-10 column (GE-Healthcare). Samples for spectroscopic titrations were sealed in a quartz cuvette (Hellma) and titration with a $\mathrm{Cu}(\mathrm{II}) \mathrm{SO}_{4}$ solution of known concentration was carried out using a gastight syringe (Hamilton). Titrations were monitored at $20{ }^{\circ} \mathrm{C}$ by UV-vis spectroscopy (700-250 nm). Protein concentrations used were in the region of $100 \mu \mathrm{M}$.

\section{Stopped-flow kinetics}

Kinetic experiments were carried out using an Applied Photophysics (Leatherhead, UK) SX20 stopped-flow spectrophotometer thermostatted at $20{ }^{\circ} \mathrm{C}$ with a Peltier system. Stocks of

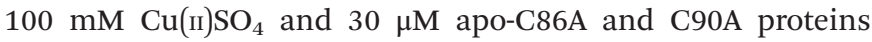
(20 mM sodium phosphate $50 \mathrm{mM} \mathrm{NaCl}, \mathrm{pH}$ 7.5) were prepared. Time courses were taken at 360 and $380 \mathrm{~nm}$ with various $\mathrm{Cu}(\mathrm{II})$ concentrations (20-1000 $\mu \mathrm{M}$ before mixing) and $15 \mu \mathrm{M}$ protein with the transients fitted to a two-step exponential function. A point to point accumulation was carried out over 320-420 nm with a step of $5 \mathrm{~nm}$ using $30 \mu \mathrm{M}$ protein and 100 to $120 \mu \mathrm{M} \mathrm{Cu(II)} \mathrm{before} \mathrm{mixing.} \mathrm{The} \mathrm{resulting} \mathrm{kinetic} \mathrm{data}$ were analysed using the programme 'ProK' (Applied Photophysics Leatherhead, UK). This programme was also employed to construct spectra of intermediates using a simple sequential model (e.g. $a>b>c)$. Analysis by singular value decomposition (SVD) was employed to determine the minimum number of species required to reconstruct the original data set. The rate constants reported are an average of triplicate experiments carried out on different days and with different protein batches. The errors reported for the global fitting of $k_{1}$ and $k_{2}$ are the standard deviation between the data sets.

\section{Acknowledgements}

We thank the University of Essex for a PhD scholarship to KLIMB.

\section{References}

1 M. Schulze and G. Rodel, Mol. Gen. Genet., 1988, 211, 492498.

2 D. M. Glerum, A. Shtanko and A. Tzagoloff, J. Biol. Chem., 1996, 271, 20531-20535.

3 T. Nittis, G. N. George and D. R. Winge, J. Biol. Chem., 2001, 276, 42520-42526.

4 L. Banci, I. Bertini, G. Cavallaro and S. Ciofi-Baffoni, FEBS J., 2011, 278, 2244-2262.

5 L. Andruzzi, M. Nakano, M. J. Nilges and N. J. Blackburn, J. Am. Chem. Soc., 2005, 127, 16548-16558.

6 Q. Ye, I. Imriskova-Sosova, B. C. Hill and Z. Jia, Biochemistry, 2005, 44, 2934-2942.

7 A. C. Badrick, A. J. Hamilton, P. V. Bernhardt, C. E. Jones, U. Kappler, M. P. Jennings and A. G. McEwan, FEBS Lett., 2007, 581, 4663-4667.

8 L. A. Abriata, L. Banci, I. Bertini, S. Ciofi-Baffoni, P. Gkazonis, G. A. Spyroulias, A. J. Vila and S. Wang, Nat. Chem. Biol., 2008, 4, 599-601.

9 J. A. R. Worrall and E. Vijgenboom, Nat. Prod. Rep., 2010, 27, 742-756.

10 M. Fujimoto, A. Yamada, J. Kurosawa, A. Kawata, T. Beppu, H. Takano and K. Ueda, Microb. Biotechnol., 2012, 5, 477488.

11 K. L. I. M. Blundell, M. T. Wilson, D. A. Svistunenko, E. Vijgenboom and J. A. R. Worrall, Open Biol., 2013, 3, 120163.

12 E. Mohorko, H. K. Abicht, D. Buhler, R. Glockshuber, H. Hennecke and H. M. Fischer, FEBS Lett., 2012, 586, 4094-4099.

13 L. Banci, I. Bertini, V. Calderone, S. Ciofi-Baffoni, S. Mangani, M. Martinelli, P. Palumaa and S. Wang, Proc. Natl. Acad. Sci. U. S. A., 2006, 103, 8595-8600.

14 E. Balatri, L. Banci, I. Bertini, F. Cantini and S. CiofiBaffoni, Structure, 2003, 11, 1431-1443.

15 E. Gaggelli, H. Kozlowski, D. Valensin and G. Valensin, Chem. Rev., 2006, 106, 1995-2044.

16 C. J. Sarell, C. D. Syme, S. E. Rigby and J. H. Viles, Biochemistry, 2009, 48, 4388-4402.

17 M. Bortolus, M. Bisaglia, A. Zoleo, M. Fittipaldi, M. Benfatto, L. Bubacco and A. L. Maniero, J. Am. Chem. Soc., 2010, 132, 18057-18066.

18 P. Davies, X. Wang, C. J. Sarell, A. Drewett, F. Marken, J. H. Viles and D. R. Brown, Biochemistry, 2011, 50, 37-47.

19 C. G. Dudzik, E. D. Walter and G. L. Millhauser, Biochemistry, 2011, 50, 1771-1777.

20 D. Valensin, F. Camponeschi, M. Luczkowski, M. C. Baratto, M. Remelli, G. Valensin and H. Kozlowski, Metallomics: Integr. Biometal Sci., 2011, 3, 292-302. 
21 C. Sacco, R. A. Skowronsky, S. Gade, J. M. Kenney and A. M. Spuches, J. Biol. Inorg. Chem., 2012, 17, 531-541.

22 Y. Bin, S. Chen and J. Xiang, J. Inorg. Biochem., 2013, 119, 21-27.

23 D. Kim, N. H. Kim and S. H. Kim, Angew. Chem., Int. Ed., 2013, 52, 1139-1142.

24 K. J. Waldron and N. J. Robinson, Nat. Rev. Microbiol., 2009, 7, 25-35.

25 K. J. Waldron, J. C. Rutherford, D. Ford and N. J. Robinson, Nature, 2009, 460, 823-830.

26 N. J. Robinson and D. R. Winge, Annu. Rev. Biochem., 2010, 79, 537-562.

27 T. R. Cawthorn, B. E. Poulsen, D. E. Davidson, D. Andrews and B. C. Hill, Biochemistry, 2009, 48, 4448-4454.

28 T. D. Wilson, M. G. Savelieff, M. J. Nilges, N. M. Marshall and Y. Lu, J. Am. Chem. Soc., 2011, 133, 20778-20792.

29 A. C. Rosenzweig, D. L. Huffman, M. Y. Hou, A. K. Wernimont, R. A. Pufahl and T. V. O'Halloran, Structure, 1999, 7, 605-617.

30 L. Whitmore and B. A. Wallace, Nucleic Acids Res., 2004, 32, W668-W673.

31 L. Whitmore and B. A. Wallace, Biopolymers, 2008, 89, 392400.

32 B. Bennett and B. C. Hill, FEBS Lett., 2011, 585, 861864.

33 Y. C. Horng, S. C. Leary, P. A. Cobine, F. B. Young, G. N. George, E. A. Shoubridge and D. R. Winge, J. Biol. Chem., 2005, 280, 34113-34122.

34 I. Imriskova-Sosova, D. Andrews, K. Yam, D. Davidson, B. Yachnin and B. C. Hill, Biochemistry, 2005, 44, 1694916956.

35 J. C. Williams, C. Sue, G. S. Banting, H. Yang, D. M. Glerum, W. A. Hendrickson and E. A. Schon, J. Biol. Chem., 2005, 280, 15202-15211.

36 L. Basumallick, R. Sarangi, S. DeBeer George, B. Elmore, A. B. Hooper, B. Hedman, K. O. Hodgson and E. I. Solomon, J. Am. Chem. Soc., 2005, 127, 3531-3544.

37 R. H. Holm, P. Kennepohl and E. I. Solomon, Chem. Rev., 1996, 96, 2239-2314.
38 Y. Lu, J. A. Roe, C. J. Bender, J. Peisach, L. Banci, I. Bertini, E. B. Gralla and J. S. Valentine, Inorg. Chem., 1996, 35, 1692-1700.

39 I. M. van Amsterdam, M. Ubbink, M. van den Bosch, F. Rotsaert, J. Sanders-Loehr and G. W. Canters, J. Biol. Chem., 2002, 277, 44121-44130.

40 G. S. Siluvai, M. Mayfield, M. J. Nilges, S. Debeer George and N. J. Blackburn, J. Am. Chem. Soc., 2010, 132, 52155226.

41 G. S. Siluvai, M. M. Nakano, M. Mayfield, M. J. Nilges and N. J. Blackburn, Biochemistry, 2009, 48, 12133-12144.

42 T. Skalova, J. Dohnalek, L. H. Ostergaard, P. R. Ostergaard, P. Kolenko, J. Duskova, A. Stepankova and J. Hasek, J. Mol. Biol., 2009, 385, 1165-1178.

43 M. A. Kihlken, A. P. Leech and N. E. Le Brun, Biochem. J., 2002, 368, 729-739.

44 L. Banci, I. Bertini, S. Ciofi-Baffoni, E. Katsari, N. Katsaros, K. Kubicek and S. Mangani, Proc. Natl. Acad. Sci. U. S. A., 2005, 102, 3994-3999.

45 T. Liu, A. Ramesh, Z. Ma, S. K. Ward, L. Zhang, G. N. George, A. M. Talaat, J. C. Sacchettini and D. P. Giedroc, Nat. Chem. Biol., 2007, 3, 60-68.

46 S. Dwarakanath, A. K. Chaplin, M. A. Hough, S. Rigali, E. Vijgenboom and J. A. R. Worrall, J. Biol. Chem., 2012, 287, 17833-17847.

47 C. Abajian and A. C. Rosenzweig, J. Biol. Inorg. Chem., 2006, 11, 459-466.

48 L. A. Compton and W. C. Johnson Jr., Anal. Biochem., 1986, 155, 155-167.

49 P. Manavalan and W. C. Johnson Jr., Anal. Biochem., 1987, 167, 76-85.

50 N. Sreerama, S. Y. Venyaminov and R. W. Woody, Anal. Biochem., 2000, 287, 243-251.

51 S. W. Provencher and J. Glockner, Biochemistry, 1981, 20, 33-37.

52 N. Sreerama and R. W. Woody, Anal. Biochem., 2000, 287, 252-260.

53 J. G. Lees, A. J. Miles, F. Wien and B. A. Wallace, Bioinformatics, 2006, 22, 1955-1962. 